\title{
Representation of Racial Diversity in Picturebooks in Teacher Education Programs in the Republic of Croatia
}

\author{
Representación de la diversidad racial en los álbumes ilustrados en \\ los programas de formación de maestros en la República de Croacia
}

\author{
Representació de la diversitat racial als àlbums il·lustrats als \\ programes de formació de mestres a la República de Croàcia
}

\author{
Matea Butković. University of Rijeka, Croatia. matea.butkovic@gmail.com \\ https://orcid.org/0000-0002-0962-435X
}

Ester Vidović. University of Rijeka, Croatia. ester.vidovic@ufri.uniri.hr

https://orcid.org/0000-0002-2553-9833

\begin{abstract}
In the Republic of Croatia, the importance of intercultural education and competence-oriented curricula has gained momentum in the last decade, with children's literature being perceived as an invaluable source of intercultural learning and a fruitful tool for an exploration of global cultural diversity. Given that empirical data indicate the importance of children's age for selecting age-appropriate intervention methods that would help combat discriminatory and prejudicial views, especially during the period between early and late childhood, this paper explores the choice of authors and picturebook titles taught in children's literary courses at six Croatian Faculties of Teacher Education (Rijeka, Pula, Zagreb, Osijek, Zadar, and Split) with the aim to determine how university instructors interpret multicultural children's literature and to which extent their syllabi accentuate the potential of picturebooks in fostering future pre-school and elementaryschool teachers' intercultural competence.

The findings indicate a misalignment between the objectives of intercultural education and the racial and ethnic representation of authors and their characters, especially protagonists. Furthermore, intercultural competence is not a major learning objective in the analyzed university syllabi. The choice of authors and picturebooks indicates a clear preference for white North American and European authors and white characters and protagonists. These findings highlight the need for teacher-educators, i.e., university instructors, to rethink the nature of their learning objectives and study content and to expand their reading lists with more diverse voices that challenge the traditional models that have historically left many ethnic groups misrepresented, under-represented, or fully omitted from school and university curricula.
\end{abstract}

Keywords: intercultural education, multicultural literature, picturebooks, teacher education, teachereducators 


\section{Resumen}

En la República de Croacia, la importancia de la educación intercultural y los currículos orientados a competencias han ganado intensidad en la última década. La literatura infantil se percibe como una fuente inestimable de aprendizaje intercultural y una herramienta productiva para la exploración de la diversidad cultural global. Dado que los datos empíricos indican la importancia de la edad de niños y niñas para seleccionar los métodos de intervención apropiados para la edad que ayudarían a combatir las perspectivas discriminatorias y perjudiciales, especialmente, durante el periodo entre infantil y primaria, este artículo explora la elección de autores y autoras y de los títulos de los álbumes que se enseñan en cursos de literatura infantil en seis facultades de magisterio de Croacia (Rijeka, Pula, Zagreb, Osijek, Zadar i Split) con la intención de determinar como los y las docentes universitarios interpretan la literatura infantil multicultural y hasta qué punto sus currículos acentúan el potencial de los álbumes ilustrados para alimentar la competencia intercultural del profesorado de infantil y primaria.

Los resultados indican una desalineación entre los objetivos de la educación intercultural y la representación étnica i racial de los autores y autoras y sus personajes, especialmente protagonistas. Aún más, la competencia intercultural no es un objetivo principal de aprendizaje en los currículos universitarios analizados. La selección de autores/as y álbumes señala una clara preferencia de autores/as blancos/as norteamericanos y europeos, y personajes protagonistas blancos. Estos resultados enfatizan la necesidad de los docentes, por ejemplo docentes universitarios, de repensar la naturaleza de sus objetivos de aprendizaje y de los contenidos de sus estudios y expandir sus listas de lectura con voces más diversas que desafíen los modelos tradicionales que han dejado históricamente determinados grupos étnicos mal representados, infrarrepresentados o completamente ausentes de los currículos escolares y universitarios.

Palabras clave: educación intercultural, literatura multicultural, álbumes ilustrados, formación docente, formación de educadores/as

\section{Resum}

A la República de Croàcia, la importància de l'educació intercultural i els currículums orientats a competències han guanyat intensitat en la darrera dècada. La literatura infantil és percep com a una font inestimable d'aprenentatge intercultural i una eina fructífera per a l'exploració de la diversitat cultural global. Atés que les dades empíriques indiquen la importància de l'edat dels infants per tal de seleccionar els mètodes d'intervenció apropiats per a l'edat que ajudarien a combatre les perspectives discriminatòries i perjudicials, especialment, durant el període entre infantil i primària, aquest article explora la tria dels autors i autores i dels títols dels àlbums que s'ensenyen en cursos de literatura infantil a sis facultats de magisteri de Croàcia (Rijeka, Pula, Zagreb, Osijek, Zadar i Split) amb la intenció de determinar com els i les ensenyants universitaris interpreten la literatura infantil multicultural i fins a quin punt els seus currículums accentuen el potencial dels àlbums il-lustrats per alimentar la competència intercultural del profesorado d'Infantil i Primària.

Els resultats indiquen una desalineació entre els objectius de l'educació intercultural i la representació ètnica i racial dels i les autors i els seus personatges, especialment protagonistes. Encara més, la competència intercultural no és un objectiu principal d'aprenentatge en els currículums universitaris analitzats. La tria d'autors i autores i àlbums assenyala una clara preferència d'autors blancs nordamericans i europeus, i personatges i protagonistes blancs. Aquests resultats emfasitzen la necessitat dels docents, per exemple docents d'universitat, de repensar la natura dels seus objectius d'aprenentatge i dels continguts dels seus estudis i expandir les seues llistes de lectura amb veus més diverses que desafien els models tradicionals que han deixat històricament determinats grups ètnics mal representats, infrarepresentats o completament omesos dels currículums escolars i universitaris.

Paraules clau: educació intercultural, literatura multicultural, àlbums il·lustrats, formació docent, formació d'educadors/es 


\section{Introduction}

The beginnings of the picturebook as an established medium can be traced back to the 19th century, while from the 1960s onwards, it has undergone a real renaissance (Narančić Kovač, 2015). In picturebooks, the two discourses, namely the verbal (linguistic) and the visual (illustrative), as Narančić Kovač (2015) observes, simultaneously participate in mediating the contents of a picturebook, while the pictures can replicate, expand, and even contradict the verbal text. One of the most thorough definitions of what the picturebook represents can be found in Bader (1976), "A picturebook is text, illustrations, total design; an item of manufacture and a commercial product; a social, cultural, historical document; and, foremost, an experience for a child" (p. 1). The modern picturebook, therefore, has not only pedagogical but also psychological, artistic, and linguistic potentials of influence on a child and can be a powerful medium when introducing multicultural literature into the teaching process since they, as agents of socialization, present an excellent opportunity to enculturate young children with open attitudes and values toward cultural diversity.

Multicultural children's literature can be defined as literature that gives voice to the sociocultural experiences of previously under-represented groups. It validates these groups' experiences, including those occurring because of differences in language, race, gender, class, ethnicity, identity, and sexual orientation. As such, it can be a catalyst for social action and increasing students' cultural awareness and sensitivity (Ford et al., 2000). Multicultural literature is, therefore, "an appropriate means of building respect across cultures, sharpening sensitivity toward the ways in which all individuals have much in common, and improving the self-esteem of people who are members of a racial and ethnic under-represented" (Norton, 1987, p. 502). In this context, picturebooks can, through readers' engagement with the semiotic meaning of the picture-text relationships, discover and critically analyze the multiple voices and ideologies represented in the narratives (Stephens, 2018).

Initial teacher education, in particular, plays a crucial role in helping preservice teachers understand the effects of cultural and racial diversity on students and providing them with the necessary competencies to use this diversity as a classroom resource in their teaching practices. As Alismail (2016) noted, "by effectively preparing preservice teachers to implement multiculturalism, these new teachers become multiculturalism's advocates, more prepared to achieve equity and social justice in their classrooms" (p. 139).

The term multiculturalism generally refers to the natural state of society that cannot but be diverse (Council of Europe, 2012), i.e., the coexistence of multilingual, multi-ethnic, and multireligious groups in a common space, whereby learning to live together in a multicultural society is the main objective of intercultural education (Council of Europe, 2012). Interculturalism is the active dimension of such 
diversity. Whereas multiculturalism evokes descriptive elements, with people from different cultures living peacefully side by side, interculturalism presupposes the relationships, interactions of individuals, groups, and communities and emphasizes their capacity to assume shared responsibilities and create common identities (Council of Europe, 2012). Beyond representing "a configuration of beliefs and practices which promote respect for and acceptance of diversity in today's societies" (Tupas, 2014, p. 243), interculturalism also addresses power structures and struggle, with its goal not being reduced to understanding, acceptance, and appreciation of cultural differences but also the transformation of the existing social order to ensure greater voice and authority to the marginalized cultures, which might lead to greater social equality and justice. As Tupas (2014) further notes, in the twenty-first century pedagogic interculturalism, this might mean broadening national education curricula to a wider range of voices and stories in the hope of greater social inclusion. Yet, given that "culture" is not a closed corpus of beliefs and representations but rather a dynamic social construct, Abdallah-Pretceille (2006) argues that the concept of "culture" is marked too much by a descriptive and categorizing approach, which might lead to students only learning about cultural stereotypes or even prejudices instead of them being provided with critical tools to analyze and contextualize that which is deemed 'cultural.' She, therefore, proposes the term "culturality" since it allows us to understand cultural phenomena "based on dynamics, transformations, fusion and manipulations. The notion of 'culturality' refers to the fact that cultures are increasingly changing, fluent, striped and alveolate" (Abdallah-Pretceille, 2006, p. 479). Hence, it is vital that practitioners and researchers "move from the idea that people are cultural objects to that of people negotiating representations on themselves, their experiences, and their environment" (Dervin, 2014, p. 193) and consider examining observed differences in a specific situation.

In the Republic of Croatia, the education system is oriented, among other things, towards the holistic development of the child and the creation of a knowledge society and values that will enable progress and sustainable development. The values that should enable holistic development are knowledge, identity, humanism and tolerance, responsibility, autonomy, and creativity (National Curriculum for Early and Pre-School Education, 2014). Furthermore, the National Curriculum Framework for PreSchool Education and General Compulsory and Secondary Education [NCF] (2010), which defines all aspects of formal education ranging from the pre-school level to the completion of secondary education, highlights "human dignity, freedom, justice, patriotism, social equality, solidarity, tolerance, industriousness, integrity, peace, health, conservation of the natural and human environment, and other democratic values" (NCF, 2010, p. 14) as the key values underpinning Croatian education. A major shift is noticed in the objectives of individual subject curricula, which increasingly place emphasis on learning outcomes as opposed to the teaching content. However, Milner (2005) underscores that 
"the very nature of this content and how it is actually incorporated into the lessons are also critical" (p. 393). In other words, it matters what is included, how, and why.

Teachers, as central actors in education, play a significant role in teaching literature. It is the teachers who adapt the materials to the students, thus respecting and accepting the different student personalities. However, for preservice teachers to be able to engage in discussions on diversity and confidently reach for appropriate teaching resources that will assist them in this challenging endeavor, it is worth exploring how teacher-educators address these same topics throughout initial teacher education. Research suggests that reading and discussing books with characters of different ethnic backgrounds can positively affect childrens' interethnic attitudes (So, 2016) as well as reading motivation and reading literacy (Becker et al., 2010). Therefore, initial teacher education should emphasize evaluation, selection, and sharing of multicultural literature.

This paper aims to determine the presence of undergraduate and graduate courses specifically addressing children's picturebooks at six Croatian Faculties of Teacher Education and how teacher-educators, i.e., university instructors, interpret the notion of multicultural children's literature in their selection of authors and titles. More specifically, it aims to explore the representation of racial diversity and the range of experiences depicted among the selected authors/illustrators and characters as a foundation for promoting the values of inclusivity, equality, and respect for racial, ethnic, and cultural diversity in the future teachers'

However, for preservice teachers to be able to engage in discussions on diversity and confidently reach for appropriate teaching resources that will assist them in this challenging endeavor, it is worth exploring how teacher-educators address these same topics throughout initial teacher education. educational practice.

\section{Toward an Intercultural and Inclusive Curriculum}

If carefully directed, the educational process can reduce and mitigate many negative socializing factors and behaviors towards people of different cultural and ethnic backgrounds (Buterin, 2009). Therefore, given the important role which school plays in disseminating values of equality, tolerance, openmindedness, and respect, among others, it is vital that the fundamental tenets of intercultural education are not mere accessories to the existing subject curricula or taught as a separate school subject; instead, it should be a principle inherent to the overall school life and culture. This means that teachers themselves need to be equipped with the knowledge and skills needed to effectively navigate through intercultural content and acknowledge their diverse students' needs. In this sense, an interculturally competent teacher might be defined as someone who "has the ability to see the relationship between culturally diverse students, the ability to mediate, interpret, critically and 
analytically understand their own culture and the culture of culturally diverse students" (Bedeković, 2011, p. 144).

One of the key concerns in intercultural education is the accurate representation of cultural and ethnic diversity in teaching materials and the regular inclusion of such materials in teachers' everyday teaching practice. Intercultural education, in its core, is not only concerned with ethnically and linguistically diverse learners but rather encompasses questions surrounding gender, class, intergenerational relations, among many others (Tupas, 2014). It is committed to combating "inequality, racism as well as sexism, and all other forms of prejudice, oppression and discrimination through the development of understanding, attitudes and social action skills" (Räsänen, 2009, p. 37) and strives to increase educational equality for all gender groups, students from diverse ethnic, cultural, and linguistic groups, and those with special educational needs. As Ladson-Billings (1994) claims, negative effects arise when one fails to notice the history, culture or background represented in textbooks or curriculum. Gay (2000) asserted that students from racially/ethnically underrepresented groups often feel "insulted, embarrassed, ashamed, and angered when reading and hearing negative portrayals of their ethnic groups or not hearing anything at all" (p. 116) and, in their research, Schneider and Preckel (2017) confirmed that course effectiveness is strongly related to what teachers do and that the choice of teaching methods has substantial effects on student achievement. It is, therefore, imperative that students from racially/ethnically underrepresented groups "encounter and experience a curriculum that highlights, showcases, and speaks from the point of view of the life experiences and contributions of people of color, women, and other marginalized groups, not just those of the White mainstream" (Milner, 2005, p. 92). Furthermore, the damage is done to students belonging to the ethnic dominant group since such cultural omissions may lead to diminished abilities to master the skills necessary for a successful life and work in a multicultural society (Buterin, 2009).

If we consider that the questioning of one's identity in relation to others is an integral part of the intercultural approach to education, then neglecting to include all students in the teaching process and failing to incorporate their communities' authentic narratives into the everyday life inside the classroom presents both the dominant and under-represented groups with "a one-sided worldview that does not correspond to reality and is clearly counterproductive to the objectives of intercultural education" (Butković, 2020). This, then, also means that intercultural education is focused on students pertaining to the dominant group. Furthermore, this indicates the importance of creating a culturallyresponsive school and teaching atmosphere that respects and actively promotes the value of each member of society and highlights the contribution of each ethnic community to the rich cultural tapestry that makes up national culture. 


\section{Importance of Age-Appropriate Interventions}

Research indicates the importance of children's age not only for selecting age-appropriate materials that would help combat or mitigate the development of stereotypical and prejudiced views in children but also for the implementation of appropriate intervention methods and the timing of such interventions (Raabe \& Beelmann, 2011), and, according to Granic and Patterson (2006), interventions seem to be more successful in age periods during which the target behavior or attitudes change per se because changing individuals are more receptive for environmental input. Therefore, it is of utmost importance that teachers understand how their work and the chosen teaching materials affect their students.

Research has shown that children begin to notice race by age two, while by age three, they show signs of being influenced by societal norms and biases and may even exhibit prejudice based on gender, race, or disability (Derman-Sparks, 1989). Furthermore, the development of children's ethnic identity is shaped between ages three and five (Bowles, 1993). In their meta-analysis, Raabe and Beelmann (2011) investigated developmental trends in prejudice by integrating empirical studies on age differences in ethnic, racial, or national prejudice among children and adolescents with the aim of gaining insights into the most appropriate point in time for implementing intervention programs. Referenced studies continuously found that prejudice increases between early (2-4 years) and middle (5-7 years) childhood and then decreases slightly between the middle (5-7 years) and late childhood (8-10 years) as well as within late childhood. In contrast, no general age trend could be confirmed in adolescence (10 years and later). On balance, it seems that age-related changes in prejudice are limited to childhood only.

On the other hand, a decrease in prejudice occurs between middle and late childhood; however, this only occurred in studies using explicit prejudice measures, whereas measurements of implicit attitudes revealed no age-related change between middle and late childhood (Banaji et al., 2008), which supports the notion that children at this age start to control their prejudiced responses (Rutland et al., 2007) and consciously evaluate different social groups. In other words, prejudice seems to change from explicit expressions to more implicit forms at elementary school age. It seems that, in the period between early and middle childhood, children start to observe positive events happening to dominant group members and negative events happening to under-represented group members. Based on these experiences, they learn explicitly or implicitly to view disadvantaged under-represented groups negatively, and advantaged dominant groups positively, even if they belong to the under-represented group themselves. Furthermore, prejudice toward higher status groups increases between middle and late childhood, which might explain that children from under-represented groups begin experiencing 
conflict between their racial identities and societal stigma and stereotypes based on their race during this period (Cole and Valentine, 2000). This indicates, in turn, that children's positive views on their racial/ethnic identities are closely connected to positive associations with their race during this age period. On the other hand, prejudice toward lower status groups remains unchanged or decreases.

Not only is children's age of vital importance for choosing the appropriate teaching strategies and materials but also teachers' awareness of its importance. Given that both teachers and students change throughout the process of intercultural education, the present research was inspired by the findings obtained in research with university students of different study programs in the Republic of Croatia, all of whom showed significant gaps in historical knowledge and implicit biases that must be addressed throughout formal education.

In their research conducted with student-teachers, Butković and Vidović (2019) found that two-thirds of students are not aware of the discriminatory attitudes and behaviors towards racial minorities in Croatia and that they struggle with the appropriateness and the role which racial nomenclature should play in children's literature. Furthermore, in a creative writing task, students of non-teaching study programs showed a clear preference $(99.85 \%)$ for white male characters (Butković \& Vidović, 2020). What is more, even the Ministry-assigned mandatory reading list for elementary schools, published in the latest Croatian Language Curriculum (2019), revealed some astounding findings. The selected authors are $100 \%$ white Europeans and their characters, unsurprisingly, are white, Christian, and European. Croatian authors on that list almost exclusively focus on the dominant Croatian population and culture, omitting to give voice to national, ethnic minorities. Furthermore, none of the protagonists' skin color is unambiguously other than white, their religion other than Christian, and their country of origin outside of Europe (Butković, 2020).

Given these findings, it is worth posing the question if initial teacher education programs are preparing new generations of teachers who are competent to address this gap between the curricular orientation toward fostering interculturally competent students and the lack of a greater ethnic and racial representation of authors and characters recorded in mandatory reading lists for the young readers.

\section{Research Aims and Questions}

This research aims to determine the presence of undergraduate and graduate courses specifically addressing children's picturebooks at six Croatian Faculties of Teacher Education (Rijeka, Pula, Zagreb, Osijek, Zadar, and Split) and how university instructors interpret the notion of multicultural children's literature in their selection of authors and titles. More specifically, it aims to explore the representation of racial diversity and the range of experiences depicted among the selected authors/illustrators and 
characters. Furthermore, learning outcomes in university courses are analyzed to determine the extent to which the selected syllabi accentuate picturebooks' potential in fostering future pre-school teachers' and elementary school teachers' intercultural competence.

Intercultural competence being "the expected outcome of the insertion of interculturality in language learning and teaching" (Dervin, 2009, p. 2), may be defined as the capacity "to see relationships between different cultures - both internal and external to a society - and to mediate, that is, interpret each in terms of the other, either for themselves or for other people" (Byram, 2000, p. 9), whereby it entails the understanding that one's "own and other cultures' perspective is culturally determined rather than natural" (p. 9). It is thereby crucial to remember that intercultural education and the fostering of intercultural competence not rely solely on the perceived cultural differences as this, according to Phillips (2010), often leads to cultural hierarchy, "There are said to be 'better' and 'worse,' 'more advanced,' and 'more backward' cultures" (p. 20), but instead to take into into account similarities across national boundaries as this would lead to a more complex and less one-sided picture of intercultural encounters (Dervin et al., 2012, p. 5).

In our endeavor, we were guided by the following research questions:

Q1: How many courses exist on children's picturebooks in six Croatian Faculties of Teacher Education?

Q2: Do the selected syllabi mention the development of intercultural competence as a learning outcome?

Q3: Does the selection of authors reflect global racial diversity?

Q4: Do the selected picturebooks include racially diverse characters (especially as protagonists)?

Q5: Does the found representation of racial diversity facilitate the advancement of equality, and can it be utilized as a vehicle for intercultural learning?

\section{Methodology}

For the purpose of this research, we searched for syllabi on children's picturebooks in undergraduate and graduate university courses at six Faculties of Teacher Education in Croatia (Rijeka, Pula, Zagreb, Osijek, Zadar, and Split), which are publically available on the Faculties' websites. This was followed by an analysis of references to intercultural competence in the selected course syllabi. Finally, we contacted the course instructors to provide us with a list of authors/illustrators and picturebook titles when these were not visible in the syllabi. Given that one of the aims of this research was to determine how university instructors interpret the notion of multicultural children's literature, we focused on their choice of picturebook authors/illustrators and human characters. 
In our analysis of authors/illustrators, we included information on the authors' nationality and race, which was identified through digital information (author websites, interviews in online media, information on book covers). This provided statistical information about what percentage of recorded national and racial diversity is considered "diverse" and "multicultural" in the corpus of analyzed authors.

For the analysis of characters, we read all the listed picturebooks and examined the illustrations. We categorized the characters into three groups: those containing only human characters, only anthropomorphized animals/objects, and a combination of human characters and anthropomorphized animals/objects. We proceeded with recording those examples that pointed to an unambiguous visual representation of racial diversity among human characters. Finally, we counted the number of picturebooks with racially diverse characters in the role of the protagonist.

\section{Research limitations}

This research was limited to the analysis of picturebooks and authors/illustrators that are addressed as part of courses dealing specifically with children's picturebooks and did not include titles mentioned in other types of children's literary courses at the aforementioned Faculties of Teacher Education. Therefore, our findings should not be understood as reflecting a uniform approach to the selection of all authors/illustrators and all children's picturebooks addressed in undergraduate and graduate university courses at the Faculties of Teacher Education in the Republic of Croatia.

\section{Results and Discussion}

The first phase of research aimed to determine the existence of undergraduate and graduate courses on children's picturebooks at six Croatian Faculties of Teacher Education (Rijeka, Pula, Zagreb, Osijek, Zadar, and Split) and how university instructors interpret the notion of multicultural children's literature in their selection of picturebook authors/illustrators and titles. This was followed by an analysis of the course learning outcomes to determine the extent to which the selected syllabi accentuate the potential of picturebooks in fostering future preschool teachers' and elementary school teachers' intercultural competence (Table 1). 


\begin{tabular}{|c|c|c|c|}
\hline $\begin{array}{c}\text { Faculty of Teacher } \\
\text { Education }\end{array}$ & Undergraduate & Graduate & $\begin{array}{l}\text { Elective/ mandatory } \\
\text { course }\end{array}$ \\
\hline Rijeka & $\begin{array}{c}\text { Picturebook - A child's first } \\
\text { book }\end{array}$ & - & elective \\
\hline Pula & - & - & - \\
\hline Zagreb & $\begin{array}{c}\text { Picturebook in the English } \\
\text { language }\end{array}$ & - & mandatory \\
\hline Osijek & - & - & - \\
\hline Zadar & - & $\begin{array}{l}\text { Picturebook and the } \\
\text { culture of reading during } \\
\text { early and pre-school age }\end{array}$ & elective \\
\hline Split & - & - & - \\
\hline
\end{tabular}

Table 1. Reference to intercultural competence in the outlined study objectives

The search for course syllabi on children's picturebooks rendered two undergraduate courses (Picturebook - A child's first book (4th semester), Picturebook in the English language (6th semester) and one graduate course (Picturebook and the culture of reading during early and pre-school age (8th semester). The compiled reading list resulted in a total of 79 authors/illustrators and 155 picturebook titles.

\begin{tabular}{|c|c|}
\hline Course & Course objectives \\
\hline $\begin{array}{l}\text { Picturebook - A child's } \\
\quad \text { first book }\end{array}$ & $\begin{array}{l}\text { - correctly interpret and analyze the basic concepts of children's literature } \\
\text { and media culture related to the picturebook } \\
\text { - independently interpret picturebooks by Croatian and foreign authors and } \\
\text { professional literature } \\
\text { - recognition of the picturebook as a combination of literary and fine arts } \\
\text { - use picturebooks independently in working with early and pre-school } \\
\text { children }\end{array}$ \\
\hline $\begin{array}{l}\text { Picturebook in the } \\
\text { English language }\end{array}$ & $\begin{array}{l}\text { - present the historical development and diversity of picturebooks in the } \\
\text { English-speaking world, with an emphasis on the narrative picturebook; } \\
\text { - distinguish and compare types of picturebooks and their characteristics; } \\
\text { - understand the problems of theoretical definition of the picturebook, the } \\
\text { complex relationship of its verbal and visual components, and other } \\
\text { constitutive characteristics of the picturebook as a multimodal art form, } \\
\text { including specific readership; } \\
\text { - explain and apply the English terminology of the theoretical description of } \\
\text { the picturebook; } \\
\text { - apply the acquired knowledge and their interpretive and analytical skills for } \\
\text { the purpose of evaluating individual picturebooks; } \\
\text { - interpret the potential of the picturebook for application in English language } \\
\text { teaching }\end{array}$ \\
\hline $\begin{array}{l}\text { Picturebook and the } \\
\text { culture of reading } \\
\text { during early and pre- } \\
\text { school age }\end{array}$ & $\begin{array}{l}\text { - understand the importance of early literacy; } \\
\text { - analyze/interpret the content of individual picturebooks; } \\
\text { - understand and distinguish the types of picturebooks and their function; } \\
\text { - recognize and evaluate the quality and appropriate picturebooks for } \\
\text { children; } \\
\text { - connect literary content with other related artistic, scientific, and general } \\
\text { cultural content (both at the synchronic and diachronic level) in an } \\
\text { interdisciplinary and intermedial manner; }\end{array}$ \\
\hline
\end{tabular}




\begin{tabular}{|l|l|}
\hline & - learn independently and progress by performing independent tasks during \\
the teaching process, depending on which language issues are defined and \\
analyzed or which topic is discussed; \\
- develop research skills at the level of writing a professional paper; \\
- develop abilities for continuous evaluation and self-evaluation of one's own \\
work and efficiency.
\end{tabular}

Table 2. Reference to intercultural competence in the outlined learning objectives

It is observable from Table 2 that the analyzed learning objectives do not specifically include acquiring or refining student-teachers' intercultural competence. They are, instead, more explicitly focused on the theoretical considerations and interpretation of children's picturebooks. Only the course Picturebook in the English language, in the syllabus section addressing the course's alignment with the broader study program objectives, includes the development of openness to different ways of creative expression, flexibility, and empathy, the improvement of students' sensitivity to the values of their own and other cultures and to the values of intercultural dialogue, and respect for diversity in the research, social and work environment. This, however, is not found in the other syllabi.

However, since we acknowledge that the term "intercultural competence" does not necessarily need to be mentioned in a course syllabus in order for that course to foster intercultural sensitivity and, thus, intercultural competence, we proceeded with the analysis of teacher-educators' choice of authors/illustrators (Figure 1) and characters (Tables 2 and 3) that would provide future teachers with a solid knowledge foundation about diverse personal narratives that could be used in their classroom practice.

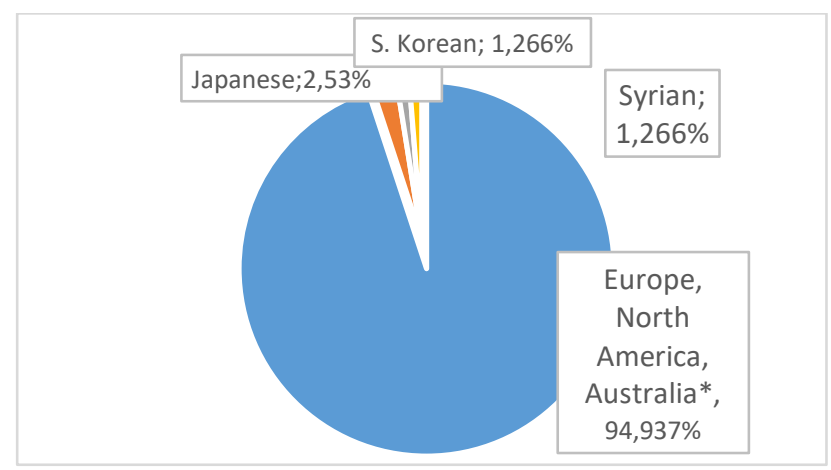

Figure 1. Choice of authors and illustrators

*Countries included in the order of frequency: Croatia, United Kingdom, United States, Australia, Canada, Russia, France, Belgium, Sweden, The Netherlands, Italy

Out of 79 authors and illustrators, as many as 75 (94.94\%) are white, and only four (5.06\%) are authors of color. Furthermore, the choice of authors reveals a clear preference for (Western) European and North American authors. This finding is similar to the research carried out by Butković (2020), who 
found that white European authors are given preference on the Ministry-assigned mandatory reading list for elementary schools.

An almost identical pattern is observed among in-service teachers' suggestions which children's authors to include on the elective readings list for elementary schools. In May 2019, following the publication of the latest Subject Curriculum for the Croatian language, the Ministry of Education issued a call to early elementary school teachers, Croatian language teachers, and school librarians to

[...] the obtained findings seem to suggest a trend in the choice of authors among teacher-educators, in-service teachers and librarians, and the competent Ministry - an over-representation of white, European authors and a virtual exclusion of authors of color. contribute to the creation of an updated elective reading list for elementary schools. Among the shortlisted authors, 98.4\% were white, and $96.3 \%$ were European (Ministry of Science and Education, 2019). While additional research is required on the choice of authors in other university syllabi, the obtained findings seem to suggest a trend in the choice of authors among teacher-educators, in-service teachers and librarians, and the competent Ministry - an over-representation of white, European authors and a virtual exclusion of authors of color.

The over-representation of white authors has been recorded in previous research (e.g., Centre for Literacy in Primary Education, 2020; NYC Coalition for Educational Justice, 2018; Koss 2015; Koss et al. 2017).

In the continuation of our analysis, we focused on the characters in the analyzed picturebooks to determine how many of them include human and non-human characters (animals and objects). This was followed by an analysis of the visual representation of racial diversity among human characters (Table 3).

\begin{tabular}{|c|c|c|c|c|}
\hline Course & $\begin{array}{c}\text { Total number } \\
\text { of picturebooks }\end{array}$ & $\begin{array}{c}\text { Human } \\
\text { characters only }\end{array}$ & $\begin{array}{c}\text { Animals/objects } \\
\text { only }\end{array}$ & $\begin{array}{c}\text { Humans and } \\
\text { animals/objects }\end{array}$ \\
\hline $\begin{array}{c}\text { Picturebook }- \text { A child's } \\
\text { first book }\end{array}$ & 12 & 3 & 9 & - \\
\hline $\begin{array}{c}\text { Picturebook in the } \\
\text { English language }\end{array}$ & 46 & 25 & 12 & 7 \\
\hline $\begin{array}{c}\text { Picturebook and the } \\
\text { culture of reading } \\
\text { during early and pre- } \\
\text { school age }\end{array}$ & 95 & 41 & 46 & 7 \\
\hline Total & $\mathbf{1 5 5}$ & $\mathbf{6 9}$ & $\mathbf{6 7}$ & $\mathbf{1 6}$ \\
\hline
\end{tabular}

Table 3. Human and non-human characters in picturebooks 
Given that our focus is on determining unambiguous examples of racial diversity, only picturebooks with human characters (69) and those that contain both human and non-human characters (16) were used in further analysis (Table 4).

\begin{tabular}{|c|c|c|c|c|c|}
\hline Course & $\begin{array}{c}\text { Number of } \\
\text { picturebooks } \\
\text { with human } \\
\text { characters }\end{array}$ & $\begin{array}{l}\text { Picturebooks } \\
\text { with racially- } \\
\text { diverse } \\
\text { characters }\end{array}$ & $\begin{array}{c}\text { Picturebooks } \\
\text { with all-white } \\
\text { characters }\end{array}$ & $\begin{array}{l}\text { Picturebooks } \\
\text { with racially } \\
\text { diverse } \\
\text { protagonists }\end{array}$ & $\begin{array}{l}\text { Picturebooks } \\
\text { with all-white } \\
\text { protagonists }\end{array}$ \\
\hline $\begin{array}{c}\text { Picturebook - A } \\
\text { child's first } \\
\text { book }\end{array}$ & 3 & - & 3 & - & 3 \\
\hline $\begin{array}{c}\text { Picturebook in } \\
\text { the English } \\
\text { language }\end{array}$ & 34 & 4 & 30 & - & 33 \\
\hline $\begin{array}{c}\text { Picturebook } \\
\text { and the culture } \\
\text { of reading } \\
\text { during early } \\
\text { and pre-school } \\
\text { age }\end{array}$ & 48 & 8 & 40 & 1 & 47 \\
\hline Total & 85 & 12 & 73 & 1 & 84 \\
\hline
\end{tabular}

Table 4. Representation of racial diversity among human characters

The final analysis has revealed a disheartening, yet not completely unexpected, result. Out of 85 picturebooks containing human characters, while only 12 picturebooks contain racially diverse characters (14.1\%). This finding is in line with research that suggests that white characters appear as the default race in children's literature (Adams, 2021; Koss \& Paciga, 2020; Welch, 2016; Centre for Literacy in Primary Education, 2020; Larrick, 1965), picturebooks (Pescosolido, et al. 1997; Edmonds, 1986), and children's board books (Hughes-Hassell \& Cox, 2010).

Given the clear dominance of white characters, it is worth highlighting the severe underrepresentation of characters of color in the role of the protagonist in the picturebooks selected by teacher-educators (Figure 2).

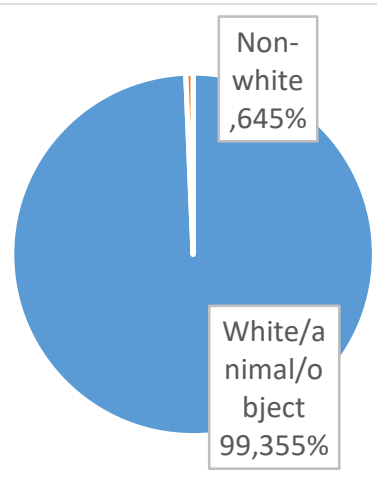

Figure 2. Chances of a non-white protagonist 
Only one picturebook (1.1\%) contains a character of color as its protagonist. Considering that this is the only example of a character of color as a protagonist in the total number of analyzed picturebooks (155), that percentage is even lower (0.65\%).

This finding means that children belonging to under-represented groups do not share that experience and are continuously exposed to narratives they do not necessarily identify with. Furthermore, the obtained findings confirm the conclusion by Butković (2020) that predominately white authors write about predominately white characters.

While it is undeniable that children enjoy reading and discovering anthropomorphized animals and objects, the Only one picturebook (1.1\%) contains a character of color as its protagonist. Considering that this is the only example of a character of color as a protagonist in the total number of analyzed picturebooks (155), that percentage is even lower $(0.65 \%)$ question is inevitably imposed on why teacher-educators seem more comfortable with selecting non-human characters for children to identify with instead of human characters of a different skin color? This question is all the more pressing if we consider that it is the teacher-educators' task to equip future teachers with the appropriate knowledge and tools to address challenges that inevitably face them in diverse classrooms. This is an area that is greatly unexplored in research and should be given more attention.

The findings related to both the recorded racial diversity among the selected authors and human characters in picturebooks leads to the conclusion that the overall corpus of selected authors and characters does not live up to the expectation of an equitable representation of racial diversity but rather favors white characters.

If student-teachers are not exposed to information and experiences that challenge their own beliefs, attitudes, and prior knowledge in a safe and carefully guided manner, then it is questionable whether those same student-teachers will instinctively reach for resources in the future teaching practice that will help them address barriers and discrimination faced by under-represented ethnic groups.

\section{Conclusion}

In the 21st century, it is imperative that children see themselves and their communities represented in the school curriculum and be continuously exposed to authentic materials that assist them in exploring who they are and how they fit into society. This, however, imposes the need on teachereducators to address these topics in their initial teacher education courses in order to equip future teachers with the knowledge and skills necessary to appropriately review existing classroom practices 
and approaches to introducing diverse narratives that challenge outdated visions of the world that remain present in school curricula.

The findings of this research indicate that intercultural competence is not a major learning objective in two out of three analyzed university syllabi (75\%). Furthermore, the choice of authors/illustrators reflects a preference for North American and Western European authors, as well as authors who are white (94.94\%). Regarding the choice of characters, in 73 picturebooks (85\%), the characters are all-white, while racially diverse characters are encountered in only 12 picturebooks (14\%). As many as 84 picturebooks (98.9\%) focus on a white protagonist, while in only one picturebook (1.1\%), the protagonist is a Roma girl. In other words, the chances to encounter a protagonist of

This, however, imposes the need on teacher-educators to address these topics in their initial teacher education courses in order to equip future teachers with the knowledge and skills necessary to appropriately review existing classroom practices and approaches to introducing diverse narratives that challenge outdated visions of the world that remain present in school curricula. color in the entire corpus of analyzed picturebooks (155) is at a disheartening $0.65 \%$. Furthermore, racial diversity does not play a (significant) role in the analyzed picturebooks, which stands in stark contrast to the objectives of intercultural and fair education that takes into account the perspectives of many groups. These findings also reveal that the teacher-educators' choice of a multicultural range of authors/illustrators and picturebooks, whereby its multicultural aspect is derived predominately from the fact that the authors/illustrators represent 14 countries, does not in and of itself ensure insight into the authentic life experiences of those members of society who have historically been discriminated against and marginalized.

If teacher-educators are viewed as designers of intercultural encounters in tertiary classrooms, for example, through the choice of materials and their implementation in the classroom setting, then their corpus of the selected authors/illustrators and picturebooks discussed here, which rely on the dominant group's perspective, cannot be understood as contributing to a critical examination of cultures that would challenge future teachers' assumptions about cultural diversity, empower them to probe critically educational content, and assist them in making informed decisions about the resources that make visible both the national and international cultural diversity. Furthermore, if our major educational aim is to provide a transformative educational experience both for future teachers and their future elementary school students, then teacher-educators must make it a priority to rethink and renegotiate the nature of their curricula from more traditional models that have historically left many ethnic groups misrepresented, under-represented, or not represented at all to curricula that are consciously more inclusive of different ethnic and racial groups. It does not suffice to only speak about 
diversity, discrimination, prejudices, and human rights abuses; concrete examples of how to combat and mitigate them need to become part of teachers' education and everyday classroom practice. This

The development of intercultural competence only makes sense if "the other" becomes an equally valuable part of the educational process, either by being part of the classroom group and/or by being visible in teaching materials, fictional or otherwise. also includes teachers' confidence and courage to choose those teaching materials and children's literature that challenge the traditional literary canon that too often omits authors, illustrators, and characters belonging to racially and ethnically underrepresented groups. The development of intercultural competence only makes sense if "the other" becomes an equally valuable part of the educational process, either by being part of the classroom group and/or by being visible in teaching materials, fictional or otherwise.

While this research has its limitations, we nevertheless hope that it is a step in the right direction in raising the awareness that teacher-educators must engage in continuous self-reflection on whether their choices and actions performed as part of their university courses assist future teachers in becoming more culturally sensitive and, thereby, more interculturally competent so that they can, in turn, continue the endeavor in their future teaching practice.

\section{References}

Abdallah-Pretceille, M. (2006). Interculturalism as a paradigm for thinking about diversity. Intercultural Education, 17(5), 475-483.

Alismail, H. A. (2016). Multicultural education: Teachers' perceptions and preparation. Journal of Education and Practice, 7(11), $139-146$.

Bader, B. (1976). American picturebooks from Noah's Ark to the Beast Within. Macmillan.

Banaji, M. R., Baron, A. S., Dunham, Y., \& Olson, K. (2008). The development of intergroup social cognition: Early emergence, implicit nature, and sensitivity to group status. In S. R. Levy, \& M. Killen (Eds.), Intergroup attitudes and relations in childhood through adulthood (pp. 197-236). Oxford University Press.

Becker, M., McElvany, N., \& Kortenbruck, M. (2010). Intrinsic and extrinsic reading motivation as predictors of reading literacy: A longitudinal study. Journal of Educational Psychology, 102, 773-785. https://doi.org/10.1037/a0020084

Bedeković, V. (2011). Interkulturalna kompetencija cjeloživotnog obrazovanja nastavnika. Pedagogijska istraživanja, 8(1), 139-151.

Bowles, D. (1993). Bi-racial identity: Children born to African-American and white couples. Clinical Social Work Journal, 21, 417-428.

Buterin, Marija. (2009). Razredno-nastavno ozračje - afirmacija interkulturalizma. Acta ladertina, 6, 73-81.

Butković, M. (2020). Whose culture? Exploring Ministry-assigned prose fiction in the Republic of Croatia. The European Conference on Education 2020 Official Conference Proceedings, The International Academic Forum (IAFOR), 435 - 454, ISSN: 2188-1162. 
Butković, M., \& Vidović, E. (2020). Developing intercultural competence via intercultural dialogue. In S. Bratož, A. Pirih, \& A. Kocbek (Eds.). Pathways to Plurilingual Education (pp. 229-240). University of Primorska Press.

Butković, M., \& Vidović, E. (2019). Student-teachers' views on racism and racial nomenclature in children's literature. Social Sciences and Humanities, 4(2), 225-248.

Byram, M. (2000). Assessing intercultural competence in language teaching. Sprogforum, 18(6), 8 - 13.

Centre for Literacy in Primary Education (2019). Reflecting realities. Survey of ethnic representation within U.K. Children's literature 2019. Arts Council England.

Cole, E. M., \& Valentine, D. P. (2000). Multiethnic children portrayed in children's picturebooks. Child and Adolescent Social Work Journal, 17(4), 305-317.

Council of Europe. (2012). Intercultural competence for all. Preparation for living in a heterogeneous world. Council of Europe Publishing.

Council of Europe. (2003). Intercultural education: managing diversity, strengthening democracy, Standing Conference of European Ministers of Education, Athens, 10-12 November 2003.

Croatian Language Curriculum. (2019). Ministry of Science and Education of the Republic of Croatia. https://narodne-novine.nn.hr/clanci/sluzbeni/2019_01_10_215.html

Derman-Sparks, L. (1989). Anti-bias curriculum: Tools for empowering young children, National Association for the Education of Young Children.

Dervin, F. (2014). Exploring 'new' interculturality online. Language and Intercultural Communication, 14(2), 191 - 206. http://dx.doi.org/10.1080/14708477.2014.896923

Dervin, F., Paatela-Nieminen, M., Kuoppala, K., \& Riitaoja, A. L. (2012). Multicultural Education in Finland: Renewed Intercultural Competencies to the Rescue? International Journal of Multicultural Education, 14(3), 1 - 13.

Dervin, F. (2009). Assessing intercultural competence in Language Learning and Teaching: a critical review of current efforts. https://kohur.icu/22022347.pdf

Edmonds, L. (1986). The treatment of race in picturebooks for young children. Book Research Quarterly, 2(3), 3041.

Ford, D. Y., Tyson, C. A., Howard, T. C., \& Harris III, J. J. (2000). Multicultural literature and gifted black students: Promoting self-understanding, awareness, and pride. Roeper Review, 22(4), 235-241.

Gay, G. (2000). Culturally, responsive teaching: theory, research, \& practice. Teachers College Press.

Granic, I., \& Patterson, G. R. (2006). Toward a comprehensive model of antisocial development: A dynamic systems approach. Psychological Review, 113, 101-13.

Hughes-Hassell, S, \& Cox, Ernie J. (2010). Inside board books: Representations of people of color. The Library Quarterly: Information, Community, Policy, 80(3), 211-230.

Koss, M. D. (2015). Diversity in contemporary picturebooks: A content analysis. Journal of Children's Literature, $41(1), 32-42$.

Koss, M. D., Martinez, M. G., \& Johnson, N. J. (2017). Where are the Latinx? Diversity in Caldecott Winner and Honor Books. Bilingual Review, 33(5), 50-62.

Koss, M. D., \& Paciga, K. A. (2020). Diversity in Newbery medal-winning titles: A content analysis. Journal of Language and Literacy Education, 16(2), 1-38.

Ladson-Billings, G. (1994). The dreamkeepers: Successful teachers of African-American children. Jossey-Bass.

Larrick, N. (1965). The all-white world of children's books. Saturday Review, 11, 63-65, 84-85. 
Milner, H. R. (2005, Winter). Developing a multicultural curriculum in a predominantly white teaching context: Lessons from an African American teacher in a suburban English classroom. Curriculum Inquiry, 35(4), 391427.

Ministry of Science and Education presented the results of a survey questionnaire on elective reading recommendations (April 26, 2019). Moderna vremena. https://mvinfo.hr/clanak/ministarstvo-znanosti-iobrazovanja-predstavilo-rezultate-anketnog-upitnika-o-preporukama-izborne-lektire

Narančić Kovač, S. (2015). Jedna priča - dva pripovjedača. Slikovnica kao pripovijed. ArTresor.

National Curriculum for Early and Pre-School Education (2014). Ministry of Science, Education, and Sports of the Republic of Croatia

National Curriculum Framework for Pre-School Education and General Compulsory and Secondary Education. (2010). Ministry of Science, Education, and Sports of the Republic of Croatia.

Norton, D. E. (1987). Through the eyes of a child: An introduction to children's literature. Merrill.

NYC Coalition for Educational Justice. (2018). Diversity in NYC elementary school curriculum: Data snapshot. http://www.nyccej.org/wp-content/uploads/2018/10/CEJ-Lack-of-Diversity-in-NYC-Curriculum-DataSnapshot-FINAL.pdf

Pescosolido, B. A., Grauerholz, E., \& Milkie, M. A. (1997). Culture and conflict: The portrayal of blacks in U.S. children's picture books through the mid- and late twentieth century. American Sociological Review, 62(3), 443-464.

Phillips, A. (2010). Gender and culture. Polity.

Raabe, T. and Beelmann, A. (2011). Development of ethnic, racial, and national prejudice in childhood and adolescence: A multinational meta-analysis of age differences. Child Development, 82(6), 1715-1737.

Räsänen, R. (2009). Teachers' Intercultural Competence and Education for Global Responsibility. In M.-T. Talib, J. Loima, H. Paavola, \& S. Patrikainen (Eds.). Dialogs on Diversity and Global Education (pp. 29 - 49). Peter Lang.

Rutland, A., Brown, R., Cameron, L., Ahmavaara, A., Arnold, K., \& Samson, J. (2007). Development of the positivenegative asymmetry effect: Ingroup exclusion norm as mediator of children's evaluations on negative attributes. European Journal of Social Psychology, 37, 171-190.

Schneider, M., \& Preckel, F. (2017). Variables associated with achievement in higher education: A systematic review of meta-analyses. Psychological Bulletin 1,143(6), 565-600.

So, J. K. (2016). Opening up spaces for early critical literacy: Korean kindergarteners exploring diversity through multicultural picturebooks. Australian Journal of Language and Literacy, 39(2), 176-187.

Stephens, J. (2018). Picturebooks and ideology. In B. Kümmerling-Meibauer (Ed.), The Routledge companion to picturebooks (pp. 137-145). Routledge.

Tupas, R. (2014). Intercultural education in everyday practice. Intercultural Education, 25(4), 243-254. http://dx.doi.org/10.1080/14675986.2014.883166

Welch, B. F. (2016). The pervasive whiteness of children's literature: Collective harms and consumer obligations. Social Theory and Practice, 42(2), 367-388.

How to cite this paper:

Butković, M., \& Vidović, E. (2021). Representation of Racial Diversity in Picturebooks in Teacher Education Programs in the Republic of Croatia. Journal of Literary Education, (4), 50-68. https://doi.org/10.7203/JLE.4.21012 